Arab World English Journal (AWEJ) Volume 12. Number1 March 2021

DOI: https://dx.doi.org/10.24093/awej/vol12no1.21

Pp. 309-324

\title{
Impact of EMI on Omani Engineering Students' Academic Performance
}

\section{Holi Ibrahim Holi Ali}

Department of English Language \& Literature University of Technology \& Applied Sciences

Rustaq, the Sultanate of Oman

Email: howlli2@yahoo.com

Received: $12 / 31 / 2020$

Accepted: 3/1/2021

Published: 3/24/2021

\begin{abstract}
Using English to teach and learn academic subjects in higher education (HE) across the globe is increasing in popularity. The overarching aim of this study is to examine the impact of English-medium instruction (EMI) on Omani engineering students' academic performance and their studies in an English-medium engineering programme in Oman. This paper reports on findings from a larger project that was intended to investigate Omani engineering students' experience of learning through the medium of English in one of the Colleges of Technology in Oman. The study adopted a qualitative interpretative approach with a case study strategy and a purposive sampling technique to look into the impact of EMI on Omani engineering students' academic performance and their studies. The sample included 12 Omani engineering and 8 engineering instructors who were interviewed along with five classroom observations. The data were collected and generated through semi-structured interviews and classroom observations. They were analysed manually, inductively and thematically using Braun and Clarke's model (2006). The findings showed that EMI had both positive and negative impacts on the students' academic performance and their studies.

Keywords: academic performance, EMI, impact; learning experiences, Omani engineering students

Cite as: Ali, H. I. H. (2021). Impact of EMI on Omani Engineering Students' Academic Performance Arab World English Journal, 12 (1) 309-324.

DOI: https://dx.doi.org/10.24093/awej/vol12no1.21
\end{abstract}


Arab World English Journal (AWEJ) Volume 12. Number 1. March 2021

Impact of EMI on Omani Engineering Students’ Academic Performance

Ali

\section{Introduction}

English as a means of instruction may be defined as the use of the English language to teach academic subjects in communities or countries where the first language (L1) of the majority of the population is not English (Dearden, 2014; Macaro, Curle, Pun, \& Dearden, 2018; Holi, 2018; Ekoç, 2020; Holi, 2020). EMI has become an important worldwide phenomenon and a matter of debate at the educational, political, and societal levels (Tollefson \& Tsui, 2003), especially in nonAnglophone countries (Scatolini, 2020). The juggernaut of EMI in non-English-speaking countries appears to be accelerating despite the notable dangers of pursuing this policy for the local language(s) and classroom practices (Kedzierski, 2016). Using EMI certainly has its merits from both students' and institutions' perspectives. However, adopting it also means that students end up learning their major subject areas in, what is for most of them, a foreign language (Kim, 2020). Internationally, there is a rapidly growing trend for English to be adopted as the medium of instruction, even when the majority of the population has another first language $(\mathrm{Vu}, 2014)$ and, in some cases, another second or even third language.

EMI has gained considerable momentum, and become an indispensable aspect of education curricula around the world (Selvi, 2020). One of the driving forces for the development of EMI has been globalization, whereby English has come to play a crucial role in assisting global academic exchange, the advancement of knowledge, and career advancement and mobility (Montgomery, 2004). However, the adoption of EMI has posed several challenges for both students and content teachers. Al-Issa conducted a study in the UAE in 2017 on the impact of EMI on students' Arabic literacy, and his findings showed that there was clear evidence showing that while Arabic as a dialect continues to be spoken and used daily, literacy in Modern Standard Arabic (MSA) is unquestionably losing ground.

Furthermore, higher education institutions (HEIs) around the world have been racing to increase the international competitiveness of their systems and to prepare graduates for the global workplace. Their attempts have often resulted in a dramatic increase in the number of EMI academic programmes in non-Anglosphere countries (Bradford, 2018). This trend is placing new pressures on faculty members concerning such things as programme design, course delivery, and classroom management, especially in EFL/ESL contexts (Bradford, 2018).

What matters in EMI teaching is the choices lecturers make in their pedagogical practice. For example, the design and implementation of their classroom instructions is key to promoting learners' responses and making learning happen (Chen, Han \& Wright, 2020). An English-only classroom language policy can have considerable effects on school achievement. Throughout schooling, learners often have low levels of ability in English (Williams \& Cooke 2002; Dutcher 2004; Aliou, Brock-Utne, Diallo, Heugh, \& Wolff, 2006). The transition of students from L1 medium to EMI creates a large gap between the learners' English language ability and the English language demands of the curriculum. These levels of language ability are often far too low to enable learners to achieve grade-appropriate levels of disciplinary knowledge. Even the pedagogy used in schools, though vary from context to context, often tends to make heavy language demands on learners in their EMI classes (Clegg \& Simpson, 2016). Additionally, learners cannot always meet all the general language-related demands on top of the more specific demands for them to master subject-specific vocabulary, register, and grammar (Clegg \& Simpson, 2016). 
Arab World English Journal (AWEJ) Volume 12. Number 1. March 2021

Impact of EMI on Omani Engineering Students’ Academic Performance

Ali

Therefore, this study adopted a qualitative interpretative approach with a case study strategy as well as semi-structured interviews and classroom observations to examine the impact of EMI on Omani engineering students' academic performance and their studies in general from a pragmatic perspective. The significance of the present study is because it drives its magnitude and from the fact that the results would help both engineering and EAP teachers to minimize the negative impact of EMI on students' academic performance.

\section{Relevant Literature Review}

Research has shown that EMI has both positive and negative effects on EFL/ESL students and their academic performance, but this depends on the students' and content teachers' levels of proficiency and training.

In their study, Xie and Curle (2020) investigated Chinese students' academic success in EMI at a Chinese state university. A questionnaire, exam score $(\mathrm{n}=100)$, and semi-structured interview data $(n=29)$ were collected from second-year undergraduate students majoring in Business Management. Content-related language proficiency and level of motivation were explored as possible significant predictors of academic success in EMI. Business English proficiency was a statistically significant predictor, highlighting that students with a lower level of proficiency needed supplementary linguistic support to fully succeed in their EMI studies. Language learning motivation did not predict academic success. Perceived success in EMI did predict actual success in EMI, highlighting the need to enhance students' perceptions of their ability to succeed in EMI. Qualitative data revealed that students' perceptions of success in EMI centred on content knowledge acquisition, improved English proficiency, knowledge application and transformation, and forming new modes of thinking. However, in the end, classroom observations enhanced the quality of the findings.

A study conducted by Lin and He (2019) investigated the effects of bilingual instruction on content-based learning and provided empirical evidence after testing influential factors in bilingual environments. After analysing a sample of 498 undergraduate students enrolled in a fundamental business course at a sample university in China, the study found insignificant statistical differences in the academic performance of bilingual and L1 (Chinese) classes. They attributed these differences to the English language support provided by the university and showed that learning competence can help students minimize language barriers and solve common learning problems facing both bilingual and L1 students. However, the study relied on corpus analysis only.

In their study, Guo, Tong, Wang, Min, and Tang (2018) used a quasi-experimental approach including Chinese college students' learning motivation, content knowledge, English language proficiency, and instructor's pedagogical practices of an English-medium instruction (EMI) class and the parallel Chinese-medium instruction (CMI) course in a non-traditional discipline. The results indicated that EMI was more effective, in comparison to CMI, in motivating the students' learning of the focal subject. More specifically, EMI students held a stronger external goal orientation than did their CMI peers. Furthermore, EMI and CMI students performed equally well in their final exam in the subject and English after one semester of participation, controlling for their prior performance. The finding suggested that EMI did not have a detrimental effect on Chinese college students' content area learning. Finally, observations revealed a significantly higher percentage of the English language instruction focused on a higher-order dense cognitive 
area in the EMI classroom where students were more engaged in their learning. Methodologically, the study relied heavily on quantitative data about the students' learning experiences of EMI. Other qualitative data collection methods, such as stories, enhanced the quality of the findings.

In their study, Vidal and Jarvis (2018) examined essays by 195 undergraduate students (99 first-year and 96 third-year) at a university in Spain to investigate the effect of three years of instruction through the medium of English on their level of proficiency, essay quality and lexical diversity (as measured by the Oxford Placement Test, the CEFR writing scale and three measures of lexical diversity). The results showed a significant improvement in the learners' second language (L2) proficiency and a significant but subtle increase in essay quality ratings, but no significant increase in lexical diversity was scored. However, since the study relied exclusively on the textual analysis of their students' essays, it would have been useful if it had also incorporated interviews with students and subject teachers to learn about their views on the impact of EMI on learning experiences and academic performance.

In a recent study, Al-Bakri (2017) explored the perceptions of students about the implementation of the EMI policy at an Omani public higher educational institution. The purpose of the study was to investigate the effects of EMI on students' learning experiences and academic performance. The findings showed that the majority of students either supported or accepted the EMI policy for utilitarian reasons, such as future employability. Students also considered the adoption of Arabic as a medium of instruction (AMI) as a plausibly helpful strategy to enhance their comprehensive understanding of disciplinary courses, and this eventually also improved their academic performance.

Al-Bakri also showed that the implementation of EMI had disempowered students with low English language proficiency. It also had a negative psychological impact on them. EMI policy was, therefore, contested as it disadvantaged some of the students, and it did not provide them with equal opportunities in education. Neither did it allow them to improve their Arabic competence.

In response to EMI, it was recommended that English language teaching in schools should be improved to better prepare students for their tertiary education. Additionally, AMI courses should be offered in all colleges to help students to comprehend their disciplinary subjects. Finally, teachers should be offered professional development activities to develop their pedagogical competencies. Al-Bakri’s general findings were corroborated by Scatolini in 2020.

However, although Al-Bakri (2017) elicited Omani students' perceptions about EMI, her study did not address the students' learning experiences in any given discipline. In this way, no light was cast upon the question of whether EMI affects students' performance in different (specific) disciplines differently.

At the same time, Al-Bakri (2017) took a critical stance towards EMI. The researcher problematised EMI without offering a genuine alternative medium of instruction that could help students to study their core subjects and function in their future workplace in the same way as English. 
Additionally, it would have been useful if the study had incorporated interviews with subject teachers and EAP teachers to learn about their views of their students' learning experiences through the medium of English. Methodologically, the study relied heavily on questionnaires for collecting the data about students' learning experiences of EMI. Other qualitative data collection methods, such as stories, would have enhanced the quality of the findings.

Another study, conducted by Dofouz and Camacho-Minano (2016), examined the impact the EMI may have on students' academic performance in comparison to their L1 (which in this case was Spanish). The data were collected from 383 financial accounting students in a Spanish university via tests that were administered during four successive academic years and analysed statistically. Overall, the findings showed that there was no statistical difference between the groups and that the use of EMI did not negatively impact students' academic performance. However, Dofouz and Camacho-Minano did not interview any students about the impact of EMI on their academic performance; rather, they relied exclusively on the analysis of their test results. Interviews and observations might have painted a different picture.

Worp (2017) conducted a study by analysing the relationship between the experiences of future professionals with EMI in the workplace, their learning experiences as language learners, their proficiency and competence in English, and their expectations of the use of English in their future career. A questionnaire was used to collect data from 194 business students at the University of the Basque Country. The findings revealed that students who had taken EMI classes demonstrated higher oral language skills and proficiency in English, and they were comfortable using English in work situations due to the amount of their exposure to the language. This study suggested that studying through the medium of English had positively impacted the students' language proficiency. The study argued that EMI might help professionals in their future careers. However, this study had a couple of limitations that merit consideration.

First, Worp (2017) only employed questionnaires to collect data about students' learning experiences as language learners and future professionals. Second, stakeholders and workplace professionals were not involved in giving their suggestions about workplace linguistic needs. Using interviews as one of the methods of data collection and involving workplace professionals might have helped to better understand students' learning experiences through the medium of English and their thoughts and expectations about their language needs in their future careers.

Another study conducted by Huang (2015) investigated the students' perceptions of the EMI courses at Southern Taiwan University of Science \& Technology (STUST) in terms of their learning motivation, learning anxiety, and learning achievement. The study included 157 participants (93 local and 64 foreign students), who completed a self-assessment questionnaire on EMI course-taking experiences. The major findings of the study were as follows. (1) Most participants were motivated to take EMI courses to strengthen their English ability and professional knowledge. (2) Most participants agreed with the helpfulness of EMI courses. (3) Interactions with students of other nationalities motivated their learning of English. (4) The local students' self-perceived low English proficiency caused them major anxiety. (5) There existed a significant reverse association between learning anxiety and achievement or motivation. (6) There existed significant differences between local and international students in measures of motivation, anxiety, and achievement. However, Huang did not interview any students about the impact of 
Arab World English Journal (AWEJ) Volume 12. Number 1. March 2021

Impact of EMI on Omani Engineering Students’ Academic Performance

Ali

EMI on their academic performance; rather, the study relied exclusively on questionnaires. Interviews and observations might have yielded a different picture.

In their studies, Shohamy (2013) and Ali (2013) suggested that when English is used in instruction, it not only helps students to acquire domain-specific knowledge but also language skills. From this, it would transpire that teaching English is not only the task of language teachers but indirectly also of content teachers. However, in reality, the latter do not concentrate on language learning during their classes as they do not see themselves as language teachers at all and have not been trained to be such, either. Generally, content teachers expected that their EFL/ESL students would be linguistically prepared for their studies before joining their speciality (Clegg \& Simpson, 2016; Huang 2015; Dearden, 2016; Vu, 2014; King, 2014; Costa \& Coleman, 2013; Airey, 2012; Aguilar \& Rodrigues, 2012; Rogier, 2012; Kerklaan, Moreira,\& Boersma, 2008). As previously suggested, some content teachers felt that they were pedagogically competent to teach content, but their own limited English language proficiency presented them with obstacles that they had not been prepared to deal with (Zacharias, 2013; Hamid, 2011; Wilkinson, 2013; Airey \& Linder, 2006).

In light of the foregoing, the researcher would argue that EMI could have a positive impact on EFL/ESL students' language development if the content courses specialists possessed higher levels of language proficiency and if their teachers were trained in how to deliver their classes through the medium of English. When both students and teachers are ill-prepared for Englishmedium classes, they equally lack the appropriate linguistic competence to ensure that EMI classes can lead to better content-based education.

Additionally, Barnard (2014) argued that most of the EFL students in Asian HEIs lack the appropriate and critical linguistic abilities to engage with academic content delivered in English or to produce original and appropriate academic texts. In this way, he suggested a dual-medium model (translanguaging), which could better enable students to cope with their content courses and the difficulties and challenges which are usually associated with studying in a language that is not one's mother tongue. This idea was also supported by Kirkpatrick (2011), who claimed that Hong Kong universities need to use a bilingual system to safeguard their local languages and promote publications in their local language. Moreover, many other researchers (Belhiah \& Elham, 2014; King, 2014; Raddawi \& Meslem, 2015; Scatolini, 2020) have advocated the need for implementing bilingual education systems, or translanguaging, to preserve the national identity and heritage and L1s such as Arabic.

\section{Research Methodology and Design}

The overarching aim of this study is to interpret and thoroughly understand Omani engineering students' perceptions about the impact of EMI on their academic performance and studies.

A qualitative methodology was used as it usually helps to address the aims and questions of studies like this and to understand social phenomena. The methodological approach to a research problem should be appropriate to the research questions and should reflect the research topic (Dörnyei \& Taguchi, 2010). 
The necessary data were generated through semi-structured interviews and observations of teaching and classroom-based learning interactions. The semi-structured interviews were the main source of data collection, and they helped the researcher to generate rich data from both engineering students and their teachers. The students' interviews were conducted in Arabic, and the data were subsequently transcribed and coded in Arabic. The relevant accounts were also translated into English.

A case study approach was adopted because the study focuses on a group of engineering students in an EMI programme in one of the Colleges of Technology in the Sultanate of Oman. The case study approach helps to study a problem in-depth within a limited time. Arguably, the case study approach was useful for the present research as it led to a better understanding of the participants' perceptions and perspectives towards the impact of EMI on their engineering education and their academic performance.

Purposive sampling was used as it entails studying information-rich cases and yields insight and in-depth understanding rather than empirical generalisations (Patton, 2002). Purposive sampling aims at capturing and describing the central themes across the case under study (Patton, 2002).

The data analysis was done manually and through the identification of themes and codes. Braun and Clarke's (2006) five phases of thematic analysis ('familiarising myself with my data', 'generating initial themes', 'searching for themes', 'reviewing themes' and 'defining and naming themes') were employed to code and analyse the data. Key ethical considerations were taken into account, such as others' opinions, anonymity, confidentiality, gaining access, acceptance and permission, informed consent and sensitivity throughout the study (Cohen, Manion, \& Morrison, 2000). The participants were explicitly told that they could withdraw from the study at any stage or any point of time if they so wished without having to explain why. Measures were taken such as member checking, triangulation, etc. to minimise the effects of design and procedures that might give an advantage to one group of participants or institute over the others and to protect the confidentiality of the data gathered and the respondents' identities and sustain the study credibility and trustworthiness

\section{Findings and Discussion}

\section{The potential impact of EMI on students and their studies}

EMI can potentially impact the students' learning experiences and their studies both positively and negatively. It may well be a positive factor in improving their English language proficiency while, at the same time, it may also be a source of hindrance to their acquisition of subject-related knowledge and skills. Based on the data collected, this part considers the impact of EMI on the students' academic performance and studies and its consequences for them.

Generally speaking, students attributed several of their low results to the implementation of EMI in their content courses in the Colleges of Technology. In this regard, student 5 (S5) stated:

Studying through the medium of English had a negative impact on my study. I need to spend much time with my English rather than concentrating on my content courses. English 
has taken much of our valuable time. Further, I find it difficult to understand exams because of the kind of technical words and instructions used and this could impact my marks and academic performance. Because of English, I need to spend much time practising for my presentations instead of focusing on core subjects. Besides, I need to spend time researching and looking up meanings of new words and finding technical meanings. I have difficulties in understanding and comprehending engineering lectures because of the level of my English. Also, I need to have much time to prepare and write my assignments to meet the deadlines. All these could be considered as challenges that have a great impact on my degree and academic performance as well.

S5 considered the mandatory EMI a waste of time and a cause of his relatively poor content learning. The time which could have gone into studying content was used to learn English. In other words, the end, including examination performance, suffered because of the medium. This would have a negative impact on his academic performance and his grade point average (GPA), which is increasingly used by major international oil and gas companies as a criterion for recruiting engineers. Also, he believed that the English language was a barrier for him to understand the engineering terms and the associated register. Additionally, the interviewee had problems with written assignments and speaking tasks. S5 found it difficult to understand what his engineering teachers were saying during lectures and classes and, so, he struggled and spent a disproportionate amount of time preparing his presentations.

Teachers, too, had their coping strategies to get around EMI, as one of them explained:

For example, if there are a few spelling mistakes in their reports, I will just overlook them because for me, yes, I am not here to teach them English (Eng. T3).

The example above suggests that engineering teachers, such as Eng. T3 had their understanding of the challenges presented to their students by mandatory EMI. In some instances, they weighed up the possible courses of action and decided that in the case of content courses, students should not be penalised because of their language mistakes, other than spelling mistakes. In other words, content teachers prioritized content over language. As long as students' reports were clear, on target and understandable to the reader, they were found acceptable. Some engineering teachers believed that their job was not to teach English, and their informal individual assessment criteria must have taken this into account.

On the other hand, S5 added:

Of course, EMI has had a negative impact on my study but at the same time, it enabled me to know my strengths and weaknesses in English in particular. My problem with English writing has impacted my assignments, projects, essays and exams.

Students like S5 reported that the use of English as the medium of instruction was useful for them and helped them to improve their language proficiency and to develop their competence as reported by S6: 
I had difficulties with reading, writing and speaking as well but things have begun to improve drastically [after joining the degree programme]. As all subjects in college are in English and this has helped me to improve my English.

However, these comments contradict the arguments raised by the majority of the students who participated in this study and served to illustrate that the individual perspectives are complex in that they are connected with each student's unique circumstances.

The findings of this study indicate that EMI had a positive impact on students who were comfortably proficient in English and a negative effect on those with low levels of proficiency. This tendency has already been identified by Kim \& Sohn (2009) in the context of EMI in South Korea. He pointed out that English was treated as more important than the content of the lectures, and students who were not competent in English found it hard to participate in the lectures. Some studies have argued that EMI can minimise interaction between faculty and students, and reduce the level of comprehension of the content of courses taught in English. Additionally, using English to teach non-English native speakers can impede discussion among students, putting those who struggle with the language in a disadvantageous position. As a result, EMI can lead to lower graduation rates (Byun, Chu, Kim, Park, Kim, \& Jung, 2011; Airey \& Linders, 2007; Collins, 2010; Al-Issa, 2017; Querol-Julián, \& Camiciottoli, 2019; Phuong, \& Nguyen, 2019).

Two-third of the interviewees who participated in this study had positive views about EMI as they believed that it helped them to improve their English language skills and that it would help them considerably in their future employment and studies. This view is the result of the ubiquitousness of English in today's job market and the high demand for professional engineers with good language proficiency in both the local and international labour markets. The findings of the present study indicated that EMI may be expected to have a significant impact on students' future employability, which will be either positive or negative depending on whether or not it has helped them improve their English language proficiency and academic attainment in engineering.

Nevertheless, the study also revealed that the participating Omani engineering students believed that the mandatory use of EMI caused them to spend much of their time studying English instead of concentrating on the technical content of the courses. S12 explained that:

They [his English-related difficulties] have a negative impact as I devote much of my time to studying English rather than engineering and telecommunication courses. The impact on my comprehension and understanding negatively as I need to read things several times to understand. I need to check online dictionaries and text my friends to ask them about unknown technical terms and concepts. Another impact was on my marks. Because of the language barriers I sometimes lose marks as I couldn't understand the questions well, or I couldn't express myself clearly when responding to exam questions. However, EMI has had a positive impact as my English was improved due to the engineering classes, and I managed to know most of the important technical vocabulary in my speciality. My writing was improved because of practising writing in the labs and writing projects and lab reports. I am able now to understand things more easily because of the engineering classes delivered in English, and I can speak to teachers and my 
classmates in English which was not possible when I was in the foundation years.

English-medium classes are great and have been useful for us.

It was apparent from the students' responses that in this particular Omani college, the chosen language of instruction was hindering the technical education of engineers, and this may have been the case elsewhere, too, given the similar approaches and students in those colleges. Sivaraman, Al Balushi, \& Rao (2014) reported similar findings elsewhere in Oman and showed that the language barrier negatively affected the performance of Omani engineering students in their engineering modules. Consequently, English as their foreign language of instruction may be regarded as partly responsible for their poor academic performance and low GPAs.

At the same time, all core subject teachers were of the view that their job was not to teach English, so their informal individual assessment criteria did not overemphasise the linguistic correctness of their students' output. This was a clear indication that the general English, EAP, ESP and the core subject teachers must come to a shared understanding of their students' linguistic needs to work towards target-oriented goals which are dictated by their students' present and future language needs. Half of the students appeared to be unable to study effectively in English after one year and a half of the full-time foundation English courses (approximately 20 hours a week) which, in turn, says something about the students themselves. Without their commitment to their learning (e.g. by preparing for lectures beforehand, previewing texts and using dictionaries and online resources to learn domain-specific vocabulary on their own), no existing language programme would be able to perform academic miracles. Therefore, considering that the students are notionally well aware of the importance of English, both in the college and the labour market, teachers across disciplines must continue to strive to motivate their students to commit themselves to learning English proactively before, during and after their content classes.

English plays a key role in the Omani gas and oil industry. Even though in everyday life, pidginised Omani Arabic may be the most common means of communication in the Sultanate, in oil and gas refineries, English is the language for spoken interaction and, above all, professional, written communication. Hence, since engineering colleges ideally prepare students for employment mostly in oil and gas refineries, English has become the undisputed means of communication in education, too. The interviewees recognised that this is part of the rationale behind EMI in Oman. Two-third of the participating students in the present study also concurred that their college offered them countless opportunities to acquire and develop their English language and communicative skills. Notwithstanding this, much of the students' time is currently being channelled into learning English rather than engineering subjects (which are the very reason why engineering students are in higher education). This imbalance in time management has repercussions. It negatively impacts students' learning and GPA. It also entails that engineering teachers have to modify, and frequently simplify, what they teach and calculate which concepts they will be able to explain in English and what their students will be able to grasp.

\section{Students' perceptions of EMI as scaffolding language proficiency}

The data collected revealed that the interviewees felt that EMI had a significant impact on their language proficiency and practice. They considered themselves empowered by the engineering classes delivered through the medium of English. Student 7 explained that: 
Using English as the medium of teaching is a challenge for us, but it has helped us to learn new terms and concepts and improve our language skills.

Some students considered EMI an important opportunity for them to maximise their exposure to English and to improve their literacy skills despite the challenges which EMI represented for them. Engineering courses in English exposed the students to the engineering register, as well as to technical terms and concepts which were, in the main, new to them. Accordingly, the students believed that their English academic literacy improved as a result of the EMI policy.

Another student added:

My engineering teachers help me with my English and they sometimes correct my grammar mistakes in my reports and projects. I use English to communicate with them and this has made me feel confident when I speak English. My speaking, writing and reading skills have improved (S8).

This student appreciated the impact of EMI on his English proficiency. Additionally, this extract illustrates, on the one hand, what an important role non-language content teachers can play a role in ensuring the success of EMI when they can coach the students, not only in the area of engineering but also occasionally in English. On the other hand, this shows that although most of the engineering teachers who were interviewed believed that their job was to teach subject contents, some of them still helped their students with their language problems. This finding corroborates that of both Xie and Curle (2020) and Vidal and Jarvis (2018).

In summary, EMI classes were of great value to students because they enhanced their language proficiency and competency. However, some of the students developed a perception that they were at a disadvantage by not being able to fully grasp the content and gain the necessary skills in their major simply because of the language barrier. Moreover, the interviews indicated that developing students' language abilities should be a shared responsibility between language and content teachers. However, to do that systemically, there must be cooperation and collaboration between the teaching staff across subjects and programmes.

\section{Conclusions, implications and recommendations}

The evidence gathered through interviews and observations strongly suggests that EMI had a positive impact on students' learning despite the challenges it presented. Students' conversations revealed their belief that EMI provided opportunities for them to improve their language proficiency, despite its corresponding challenges and difficulties. This suggests that the use of EMI in Omani engineering education should be promoted and sustained as it enhances the students' language competence and enables them to find good jobs in the future in engineering-related industries. However, a considerable number of the participants expressed their concerns about EMI and its impact on their academic achievements and their GPAs. Further evidence comes from several studies, which indicated undesirable effects of EMI on students and their studies, indicating that EMI minimises interactions between faculty and students; reduces the level of comprehension of the content of the course; impedes discussions among students; disadvantages students with low proficiency; and it lowers graduation rates (Byun et al., 2011; Airey \& Linders, 
2007; Collins, 2010). In contrast, engineering and EAP teachers believed that EMI had a positive effect on students and their future career regardless of the challenges the EMI presented to EFL/ESL students. This suggests that higher education institutions need to ensure offering appropriate EMI infrastructures and promoting adequate pre-university preparation courses before launching their EMI programmes and degrees. This would enable students to study their disciplinary courses successfully and minimise EMI language-related challenges and difficulties. To run an effective EMI programme, higher education institutions need to meet successful EMI implementation needs, demands and requirements. The dialogue between engineering teachers and EAP teachers should take place before implementing EMI programmes by creating bridges between them to avoid any barriers that might arise in the future.

From the study, several implications and recommendations can be ensured to help improve the content, provision and delivery of EAP courses. They could also assist engineering teachers with the delivery of their content courses in English and their students with their language-related challenges and difficulties. The findings of the present study could also help the designers of EAP/ESP textbooks and materials as well as of teacher training programmes. In this way, the potential negative impact of EMI on students could be reduced. Furthermore, the study recommends that engineering teachers and EAP teachers need to collaborate to promote students' language proficiency in their engineering classes and to address the negative impact of EMI on students' academic performance and their studies. Finally, engineering teachers should be trained on pedagogical issues and how to use EMI successfully and purposefully to release the great potential of EMI higher education in Oman.

\section{About the Author:}

Holi Ibrahim Holi Ali, Ph.D. is an assistant professor of applied linguistics \& TESOL at the Department of English Language \& Literature, University of Technology and Applied Sciences, Rustaq, Sultanate of Oman. He has a $\mathrm{PhD}$ in applied linguistics from the University of Huddersfield, UK. His teaching and research interests include English medium of instruction (EMI) in higher education, language education and literacy, translation studies, theoretical linguistics, applied linguistics and TESOL. He has presented widely and published extensively in peer-reviewed journals.ORCID: https://orcid.org/0000-0002-0608-6146

\section{References}

Al-Bakri, S. (2017). Effects of English medium instruction on students' learning experiences and quality of education in content courses in a public college in Oman. Unpublished $\mathrm{PhD}$. Thesis, University of Exeter, UK.

Aguilar, M. \& Rodríguez, R. (2012). Lecturer and student perceptions on CLIL at a Spanish university. International Journal of Bilingual Education and Bilingualism, 15(2), 183-197. https://doi.org/10.1080/13670050.2011.615906

Airey, J. (2012). I don't teach language: The linguistic attitudes of physic lecturers in Sweden. AILA Review, 25(1), 64-79. Doi: https://doi. 10.1075/aila.25.05air 
Arab World English Journal (AWEJ) Volume 12. Number 1. March 2021

Impact of EMI on Omani Engineering Students' Academic Performance

Ali

Airey, J., \& Linder, C. (2006). Language and the experience of learning university physics in Sweden. European Journal of Physics, 27(3), 553-560. Doi: https://doi. 10.1088/01430807/27/3/009

Alidou, H., B. Aliou, B. Brock-Utne, Y. S. Diallo, K. Heugh., \& H. E. Wolff. (2006). Optimizing Learning and Education in Africa - The Language Factor; A Stock-taking Research on Mother Tongue and Bilingual Education in SubSaharan Africa. Paris: Association for the Development of Education in Africa.

Al-Issa, A. (2017). English as a medium of instruction and the endangerment of Arabic literacy: The case of the United Arab Emirates. Arab World English Journal (AWEJ), 8(3), 3-17. https://dx.doi.org/10.24093/awej/vol8no3.1

Ali, N. L. (2013). A changing paradigm in language planning: English-medium instruction policy at the tertiary level in Malaysia. Current Issues in Language Planning, 14(1), 73-92. https://doi.org/10.1080/14664208.2013.775543

Barnard, R. C. (2014). English medium instruction in Asian Universities: Some concerns and a suggested approach to dual-medium instruction. Indonesian Journal of Applied Linguistics, 4(1), 10-22. Doi: https://doi.10.17509/ijal.v4i1.597

Belhiah, H., \& Elham, M. (2015). English as a medium of instruction in the Gulf: When students and teachers speak. Journal of Language Policy, 14(3), 3-23. Doi: https://doi.org/10.1007/s10993-014-9336-9

Bradford, A. (2018). It's not all about English! The problem of language foregrounding in Englishmedium programmes in Japan. Journal of Multilingual and Multicultural Development, 40(8), 707-720. https://doi.org/10.1080/01434632.2018.1551402

Braun, V. \& Clarke, V. (2006). Using thematic analysis in Psychology. Qualitative Research in Psychology, 3(2), 77-101.

Byun, K., Chu, H., Kim, M., Park, I., Kim, S., \& Jung, J. (2011). English-medium teaching in Korean higher education: Policy debates and reality. Higher Education, 62(4), 431-449. http://dx.doi.org/10.1007/s10734-010-9397-4

Chen, H., Han, J., \& Wright, D. (2020). An Investigation of Lecturers' Teaching through English Medium of Instruction-A Case of Higher Education in China. Sustainability, 12, 1-16. Doi:https://doi.10.3390/su12104046

Clegg, J. \& Simpson, J. (2016). Improving the effectiveness of English as a medium of instruction in sub-Saharan Africa. Comparative Education 52(3), 359-374. Doi: .https: doi.10.1080/03050068.2016.1185268

Cohen, L., Manion, L. \& Morrison, K. (2000). Research Methods in Education (5th Edition) London: Routledge Falmer.

Collins, A.B. (2010). English-medium higher education: dilemma and problems. Eurasian Journal of Educational Research, 39, 97-110. http://hdl.handle.net/11693/48964

Costa, F. \& Coleman, J. A. (2013). A survey of English-medium instruction in Italian higher education. International Journal of Bilingual Education and Bilingualism, 16(1), 3-19. Doi: https://doi.org/10.1080/13670050.2012.676621

Dafouza, E., \& Camacho-Miñano, M. M. (2016). Exploring the impact of English-medium instruction on university student academic achievement: The case of accounting. English for Specific Purposes, 44, 57-67. Doi:https://doi.org/10.1016/j.esp.2016.06.001

Dearden, J. (2016). English as a medium of instruction - a growing global phenomenon. British Council: UK. Retrieved November 2015, from www.teachingenglish.org.uk 
Arab World English Journal (AWEJ) Volume 12. Number 1. March 2021

Impact of EMI on Omani Engineering Students' Academic Performance

Ali

Dearden, J. (2014). English as a medium of instruction-a growing global phenomenon. London: British Council. Doi: https://doi. 10.13140/RG.2.2.12079.94888

Denscombe, M. (2010). The good research guide for small-scale social research project (4th ed.). Buckingham: Open University Press.

Dörnyei \& Taguchi (2010). Questionnaire in second language research: construction, administration, and processing. UK: Routledge.

Dutcher, N. (2004). Expanding Educational Opportunities in Linguistically Diverse Societies. Washington, DC: Centre for Applied Linguistics.

Ekoç, A. (2020). English medium instruction (EMI) from the perspectives of students at a technical university in Turkey. Journal of Further and Higher Education, 44(2), 231-243.Doi:https//doi. 10.1080/0309877X.2018.1527025

Guo, H., Tong, F., Wang, Z., Min, Y. \& Tang, S. (2018). English-vs. Chinese-medium instruction in Chinese higher Education: A quasi-experimental comparison. Sustainability 10(11), 1-17. Doi.https://doi. 10.3390/su10114230

Hamid, M. O. (2011). Globalisation, English for everyone and English teacher capacity: Language policy discourses and realities in Bangladesh. Current Issues in Language Planning, 11(4), 289-310. Doi: https://doi.org/10.1080/14664208.2011.532621

Holi, I. H. (2020). Lecture comprehension difficulties experienced by Omani students in an English medium engineering programme, Cogent Arts \& Humanities, 7(1), 1-17. Doi:https:// doi:10.1080/23311983.2020.1741986

Holi, I. H. (2018).Omani Engineering Students' Experiences of Learning through the Medium of English. Unpublished PhD thesis, University of Huddersfield, UK.

Huang, D. (2015). Exploring and assessing effectiveness of English medium instruction courses: The students' perspectives. Procedia - Social and Behavioural Sciences, 173, 71 - 78.Doi: https://doi.org/10.1016/j.sbspro.2015.02.033

Kakepoto, I. Omar, N. A. M., Boon, Y., \& Iqbal, S., M, Z. (2012). Perspectives on oral communication skills for engineers in the engineering profession of Pakistan. International Journal of Applied Linguistics and Literature, 1(5), 176183.Doi:https//doi.10.7575ijalel.v.In.5p.176.

Lin, T., \& He, Y. (2019). Does Bilingual Instruction Impact Students' Academic Performance in Content-Based Learning? Evidence from Business School Students Attending Bilingual and L1 Courses. Sustainability 11, 1-18.Doi:https://doi: 10.3390/su11010263

Kedzierski, M. (2016). English as a medium of instruction in East Asia's higher education sector: a critical realist Cultural Political Economy analysis of underlying logic. Comparative Education, 52(3), 375-391.Doi:https://doi:10.1080/03050068.2016.1185269

Kerklaan, V., Moreira, G., \& Boersma, K.(2008). The role of language in the internationalisation of higher education: An example from Portugal. European Journal of Education, 43(2), 241255

Kim, Y. (2020). The Value of Interactive Polling and Intrinsic Motivation When Using English as a Medium of Instruction. Sustainability 12, 1-13.Doi:https://doi:10.3390/su12041332

Kim, S.K, Sohn \& S., Y. (2009). Expert system to evaluate English medium instruction in Korean Universities. Expert Systems with Applications 36(9), 1162611632.Doi:https://doi. 10.1016/j.eswa.2009.03.026

Arab World English Journal 
Arab World English Journal (AWEJ) Volume 12. Number 1. March 2021

Impact of EMI on Omani Engineering Students' Academic Performance

Ali

King, J.M. (2014). An exploratory investigation into content teacher views on English as a medium of instruction policy enactment in the UAE Feral Tertiary Sector. Unpublished PhD thesis, the University of Exeter. http://hdl.handle.net/10871/17359

Kirkpatrick, A. (2011). English as an Asian lingua franca and the multilingual model of ELT. Language Teaching, 44(2), 212-224. Doi: https://doi.org/10.1017/S0261444810000145

Macaro, E., S., Curle, J. Pun, J. An., \& J. Dearden. (2018). A Systematic review of English medium instruction in Higher education. Language Teaching, 51(1), 36-76. Doi: https://doi.org/10.1017/S0261444817000350

Montgomery, S. (2004). Of towers, walls, and fields: Perspectives on language in science. Science 303(5662), 1333-1335.Doi:https:// doi:10.1126/science.1095204

Patton, M. Q. (2002). Qualitative research and evaluation methods $\left(3^{\text {rd }}\right)$. Newbury Park: Sage.

Phuong, Y., H., \& Nguyen, T. T. (2019). Students' Perceptions towards the Benefits and Drawbacks of EMI Classes. English Language Teaching; 12(5), 88-100.Doi: https://doi: 10.5539/elt.v12n5p88

Querol-Julián, M., \& Camiciottoli, B.C. (2019). The Impact of Online Technologies and English Medium Instruction on University Lectures in International Learning Contexts: A Systematic Review. ESP Today, 7(1), 1-23. https:// doi.org/10.18485/esptoday.2019.7.1.1

Rogier, D. (2012). The effects of English-medium instructions on language proficiency of students in higher education in the UAE. Unpublished doctoral thesis, University of Exeter, UK.

Raddawi, R., \& Meslem, D. (2015). Loss of Arabic in the UAE: Is bilingual education the solution? International Journal of Bilingual \& Multilingual Teachers of English, 30(2), 85-94.

Scatolini, S. S. (2020). Perceptions of English as a medium of instruction (EMI) in Oman. In Sergio Saleem Scatolini and Milton A. George (eds), Education and society in the Middle East and North Africa: English, citizenship and peace education (pp. 117-138). Newcastle upon Tyne: Cambridge Scholars Publishing.

Shohamy, E. (2013). Critical perspective on the use of English as a medium of instruction at universities. In A. Doiz, D. Lasagabaster and J.M. Sierra (Eds.), English-medium instruction at universities: Global challenges (pp. 196-210). Multilingual Matters, Bristol: UK. Doi:

10.21832/9781847698162-014

Sivaraman, I., Al Balushi, A., \& Rao, D.H. (2014). Understanding Omani students' (University) English language problems. International Journal of Sciences: Basic and Applied Research (IJSBAR), 3(1), 28-35

Selvi, A.F. (2020). Resisting English medium instruction through digital grassroots activism. Journal of Multilingual and Multicultural Development. https://doi.org/10.1080/01434632.2020.1724120

Tollefson, J.W., \& Tsui, A.B. (2003).Medium of instruction policies: Which agenda? Whose agenda? Mahwah: Lawrence Erlbaum. Routledge.

Vidal, K., \& Jarvis, S. (2018). Effects of English-medium instruction on Spanish students' proficiency and lexical diversity in English. Language Teaching Research, 1-20. Doi: https://doi.org/10.1177/1362168818817945

$\mathrm{Vu}$, N. T. T. (2014). English as a medium of instruction: Challenges for Vietnamese Tertiary Lecturers. The Journal of Asia TEFL, 11(3), 1-31. http://www.asiatefl.org/main/download_pdf.php?i=59\&c=1412065511\&fn=11_3_01.pdf

Williams, E., \& J. Cooke. (2002). Pathways and Labyrinths: Language and Education in Development. TESOL Quarterly 36(3): 297-322. Doi: https://doi.org/10.2307/3588415 
Wilkinson, R. (2013). English-medium instruction at a Dutch university: Challenges and pitfalls. In A. Doiz, D. Lasagabaster, \& J. M. Sierra (Eds.), English-medium instruction at universities: Global challenges (pp. 3-24). Bristol, UK: Multilingual Matters. Doi: https://doi.org/10.21832/9781847698162-005

Worp, K.V D. (2017). English medium instruction: away towards linguistically better-prepared professionals in the Basque Autonomous Community? International Journal of Multilingualism, 14(1), 53-68.Doi: https://doi.org/10.1080/14790718.2017.1258994

Xie, W., \& Curle, S. (2020). Success in English Medium Instruction in China: significant indicators and implication. International Journal of Bilingual Education and Bilingualism. Doi.org/10.1080/13670050.2019.1703898

Zacharias, N. T. (2013). Navigating through the English-medium-of-instruction (EMI) policy: Voices from the field. Current Issues in Language Planning, 14(1), 93-108. Doi: https:// doi.org/ 10. 1080/14664208.2013.782797 